\title{
Phytochemical Screening and Biological Activity of Calotropis Procera (Ait). R. Br. (Asclepiadaceae) Against Selected Bacteria and Anopheles stephansi Larvae
}

\author{
Hiren Doshi ${ }^{1, *}$, Hitesh Satodiya ${ }^{1}$, Mukund Chandra Thakur ${ }^{2}$, Farzin Parabia $^{2}$, Arif Khan ${ }^{2}$ \\ ${ }^{1}$ Dept. of Pharmaceutical Chemistry \\ ${ }^{2}$ Dept. of Biotechnology; Ashok \& Rita Patel Institute of Integrated Study \& Research in Biotechnology and Allied Sciences, New Vallabh \\ Vidyanagar, 388121, Gujarat, India
}

\begin{abstract}
The ethanol extracts of flowers, young bud, mature leaves and stems of Calotropis procera (Ait). R. Br. (Asclepiadaceae) was screened for phytochemical properties, antimicrobial (agar dilution method) activity and effectiveness on third instar larvae of Anopheles stephansi. Qualitative estimation of alkaloids, carbohydrates, glycosides, saponins, proteins, fixed oils, starch, triterpenoid, phenolics and tannins showed their presence in almost all the plant part extracts. While, gum and mucilage were absent in all the plant extracts. Quantitative estimation of different parts of the plant extracts had large quantity of carbohydrate and tannin in flower while young buds had higher amount of phenolic compounds and oil. Mature leaves showed maximum activity against all the bacterial strain used in the study. The extracts of mature leaves showed highest activity of $100 \%$ mortality at $2000 \mathrm{ppm}$ after 48 hours of incubation against 3rd instar larvae of A. stephansi. LD50 and LD90 values suggested that mature leaves of $C$. procera had higher mortality rate against larvae of A. stephansi.
\end{abstract}

Keywords Anopheles Stephansi, Calotropis Procera, Larvicidal Activty, LD50, LD90, Microbial Activity \& Plant Extracts

\section{Introduction}

Plant produces a wide range of bioactive molecules via secondary metabolic pathways. Most of these molecules have been developed on the basis of traditional knowledge in health care and in many cases, there is a correlation between the indications of pure substances and those of respective crude extracts used in traditional medicine[1]. Plants are important source for the discovery of novel pharmacologi-cally active compounds. Many drugs are derived directly or indirectly from plants[2] which are used as antimicrobial and antifungal agents[3]. Despite the advances in antimicrobial therapies, many problems remained to be solved for the most antimicrobial drugs available[4].

In many developing countries, malaria and other vector-borne diseases are of major concern due to improper sanitation, inappropriate treatment and devoid of access to clean water[5]. Malarial contributes to the major disease in India[6]. One of the methods to control is to control the

* Corresponding author:

drhirendoshi@yahoo.co.in (H. Doshi)

Published online at http://journal.sapub.org/ journal abbreviation

Copyright (C) 2011 Scientific \& Academic Publishing. All Rights Reserved vectors for eradication of disease transmission. Use of synthetic insecticides to control the insect pests has resulted in development of resistance in some vectors of malaria, filariasis and dengue fever[7]. In last few decades, the findings of various natural plant products against mosquito vectors have proved to be an alternative to the synthetic chemicals[8-15].

Anopheles stephansi Linn. (Diptera, Culicidae), the vector which transmit malaria are disseminated everywhere within the world. In addition, A. stephansi population is highly resistant to insecticides[16]. It would be of great relevance to search for alternatives in combating malaria and proliferation of A. stephansi.

Many natural compounds have been suggested as alternatives against conventional chemical control[17]. The genus Calotropis has attained a high repute for its various medicinal properties[18, 19]. The plant $C$. procera belonging to the family Asclepiadaceae was selected for the present work. This large family comprises of around 175-180 genera and 2200 species distributed in the tropical and subtropical region. Many of which possess biologically active compounds[20]. Calotropis is a small genus having 6 species of shrubs or small trees, distributed in tropical and subtropical Africa, Asia and America. Two species namely $C$. procera and $C$. gigantae are found in India which closely 
resembled to each other in structure and in functional uses[21].

\section{Materials and Methods}

\subsection{Collection and Identification of Plant Material}

Fresh Flowers, young buds, mature leaves and stem of $C$. procera were collected from Vallabh Vidyanagar and neighbouring farm areas of Anand district, Gujarat. The samples were clean and packed in polythene bag separately. Flowers, young bud, mature leaves and stems of $C$. procera are abbreviated as $\mathrm{Cp}-\mathrm{f}, \mathrm{Cp}-\mathrm{b}, \mathrm{Cp}-\mathrm{l}$ and $\mathrm{Cp}-\mathrm{s}$ respectively.

\subsection{Extraction of Phytochemicals}

Plant materials ( $\mathrm{Cp}-\mathrm{f}, \mathrm{Cp}-\mathrm{b}, \mathrm{Cp}-\mathrm{l}$ and $\mathrm{Cp}-\mathrm{s})$ were washed with running tap water followed by distilled water. The samples were blotted and dried with the help of absorbent towels and cut into small pieces. The fresh plant materials were processed for ethanol extraction using soxhlet apparatus. The extracts were filtered through Whatman no.1 filter paper, concentrated under vacuum and stored at $10-$ $15^{\circ} \mathrm{C}$ for further use.

\subsection{Phytochemical Screening}

\subsubsection{Qualitative Analysis}

All ethanol extracts plant materials (Cp-f, $\mathrm{Cp}-\mathrm{b}, \mathrm{Cp}-\mathrm{l}$ and $\mathrm{Cp}$-s) were analysed for alkaloids, carbohydrate, glycosides, saponins, proteins, phytosterols, phenolic compounds, tannins, gum, mucilage as described by Raman[22].

\subsubsection{Quantitative Estimation}

The ethanol extracts of plant materials (Cp-f, Cp-b, Cp-l and $\mathrm{Cp}$-s) were subjected to the quantitative phytochemical screening for total carbohydrate[23], total protein[24], tannins \& phenolic compounds[25], crude alkaloid[26] and oil (lipid)[27].

\subsection{Determination of Antibacterial Activity}

In present study, pure culture each of four Gram positive (Bacillus cereus, B. subtilis, Staphylococcus aureus, Micrococcus luteus) and Gram negative bacteria (Escherichia coli, Salmonella typhi, Pseudomonas aeruginosa, Serratia marcescens) were obtained from MTCC Chandigarh. Antibacterial susceptibility testing was carried out by agar disc diffusion method[28]. The uniform growth rate was maintained on nutrient broth (Hi Media, $\mathrm{pH}$ 7.4) at $1 \times 10^{8} \mathrm{cfu} / \mathrm{ml}$. The bacterial culture was compared with $0.5 \mathrm{Mc}$ Farland turbidity standards, which is equivalent to $1 \times 10^{8} \mathrm{cfu} / \mathrm{ml}$ bacterial cell density[28].

\subsubsection{Antibacterial Susceptibility Test by Agar Disc Diffusion Method}

The above inoculums of each bacterial strain $(200 \mu \mathrm{l})$ were added to autoclaved nutrient agar plate (Hi media) at a temperature of near about $45^{\circ} \mathrm{C}$. Sterile disc $(7 \mathrm{~mm})$ was saturated with $5 \mu \mathrm{g}$ of the ethanol extracts at room temperature. The disc was introduced on the upper layer of the seeded agar plate and incubated at $37^{\circ} \mathrm{C}$ for 24 hours. The zone of inhibition on medium plates was measured as antimicrobial activity. The experiments were performed under strict aseptic conditions in triplicate.

\subsection{Efficacy against Larva of $A$. stephansi}

The efficacy of active principle of different parts of $C$. procera was evaluated for larvicidal activity against third instar larvae of A. stephansi (vector mosquito). Fresh formulation of extracts ranging from 100 to $5000 \mathrm{ppm}$ was prepared. The larvae of $A$. stephansi were chosen from the culture and released in $100 \mathrm{ml}$ of test formulation taken in glass beakers in triplicate. A minimum of 25 larvae were exposed at each time for individual plant extract. The beakers were covered with fine muslin cloth and kept at room temperature for 5, 24 and 48 hours. The percentage mortality of larvae was subjected for regression analysis. $\mathrm{D}_{50}$ and $\mathrm{LD}_{90}$ values were also calculated as per the procedure described by Acharya et al.[29].

\section{Results and Discussion}

Ethanol extractable values of $C$. procera are given in Table 1. The higher amount of the extract was obtained in $\mathrm{Cp}$-f sample followed by $\mathrm{Cp}-\mathrm{l}, \mathrm{Cp}-\mathrm{b}$ and $\mathrm{Cp}$-s. Therefore, the flower could be the best option for the study of alkaloid content. Phytosterol were observed only in Cp-b and Cp-1 samples while flavonoids were present in all the extracts except Cp-s. Gum and Mucilage were absent in all the extracts. $\mathrm{Cp}$ - $\mathrm{f}$ contained higher amount of carbohydrate and tannin than $\mathrm{Cp}-\mathrm{b}, \mathrm{Cp}-\mathrm{l}$ and $\mathrm{Cp}$-s while $\mathrm{Cp}-\mathrm{b}$ contained larger quantity of phenolic compounds and oil (Table 2). Proteins were more in $\mathrm{Cp}-\mathrm{l}$ as compared to rest of the plant parts. Our findings are in agreement with the results reported by several researchers[30-32].

Table 1. Ethanol extractive value of plant C. procera

\begin{tabular}{cccc}
\hline Sample & $\begin{array}{c}\text { Initial weight of } \\
\text { sample }(\mathrm{g})\end{array}$ & Final extract $(\mathrm{g})$ & Residue (g) \\
\hline Cp-f & 120 & 6.00 & 114 \\
Cp-b & 120 & 5.10 & 114.90 \\
Cp-1 & 120 & 5.60 & 114.40 \\
Cp-s & 120 & 4.00 & 116 \\
\hline
\end{tabular}

Table 2. Quantitative estimation of whole plant material

\begin{tabular}{ccccc}
\hline \multirow{2}{*}{ Phytoconstituents } & \multicolumn{4}{c}{ Value (g \%) } \\
\cline { 2 - 5 } & Cp-f & Cp-b & Cp-1 & Cp-s \\
\hline Carbohydrate & 22 & 8 & 9 & 13 \\
Proteins & 3 & 15 & 22 & 11 \\
Tannin & 1 & 0.9 & 0.8 & 0.6 \\
Phenolic compounds & 0.7 & 2.30 & 1.3 & 1.8 \\
Crude Alkaloid & 0.25 & 1.8 & 0.25 & 1.4 \\
Oil(Lipid) content & 1.2 & 5.6 & 3.3 & 2.1 \\
\hline
\end{tabular}

The extractable active compound from flower and stem of 
C. procera ( $\mathrm{Cp}$-f and $\mathrm{Cp}$-s respectively) did not show antibacterial activity against any of the bacterial strain (Table 3). Cp-b extract showed the inhibition zone S. aureus (Gram positive), S. typhi (Gram negative). While, $\mathrm{Cp}$-1 showed the inhibition zone against all the bacterial isolates studied. There is a profound effect on Gram positive bacteria than that of Gram negative bacteria for both $\mathrm{Cp}-\mathrm{b}$ and $\mathrm{Cp}-\mathrm{l}$. The inhibition zone of different plant extracts ranged between $1-10 \mathrm{~mm}$ on the plate. The antibacterial activity is categorized on the basis of inhibition zone. The inhibition zone $>10 \mathrm{~mm}$ has been considered as good activity; 6-9 $\mathrm{mm}$, moderate activity; $1-5 \mathrm{~mm}$, least activity and $<1$ no activity[33].

Table 3. Antibacterial activity of the ethanol extractable material of a selected plant parts

\begin{tabular}{|c|c|c|c|c|}
\hline Plant Extracts & \multicolumn{4}{|c|}{ Zone of inhibition (mm) (MIC)in $\mu \mathrm{g} / \mathrm{ml}$} \\
\hline \multicolumn{5}{|c|}{ Gram Positive bacteria } \\
\hline & B. cereus & B. subtilis & S. aureus & M. luteus \\
\hline Cp-f & - & - & - & - \\
\hline $\mathrm{Cp}-\mathrm{b}$ & - & - & 8 & - \\
\hline Cp-1 & 13 & 15 & 7 & 9 \\
\hline $\mathrm{Cp}-\mathrm{s}$ & - & - & - & - \\
\hline \multicolumn{5}{|c|}{ Gram Negative bacteria } \\
\hline & E. coli & S. typhi & P. aeruginosa & S. marcescens \\
\hline $\mathrm{Cp}-\mathrm{f}$ & - & - & - & - \\
\hline $\mathrm{Cp}-\mathrm{b}$ & - & 4 & - & - \\
\hline Cp-1 & 10 & 5 & 6 & 5 \\
\hline $\mathrm{Cp}-\mathrm{s}$ & - & - & - & - \\
\hline
\end{tabular}

- indicates no inhibition

In general, Gram positive bacteria show more sensitivity against most of the antibacterial agent to Gram negative bacteria. Gram negative bacteria having an outer phospholipid membrane carrying the structural lipopolysaccharide components, this makes the cell wall impermeable to lipophilic solutes, while protein constitutes a selective barrier to the hydrophilic solutes[34]. However, in our study, both Gram positive and Gram negative bacteria were sensitive against all the plant extracts.

Different parts of the plants were tested and showed a significant larvicidal activity of ethanolic extracts. Cp-1 showed maximum activity against $3^{\text {rd }}$ instar larvae of the mosquito which exhibited $100 \%$ mortality at $2000 \mathrm{ppm}$ after 48 hours of incubation (Figure 1). $\mathrm{LD}_{50}$ and $\mathrm{LD}_{90}$ values of $\mathrm{Cp}-\mathrm{f}, \mathrm{Cp}-\mathrm{b}, \mathrm{Cp}-\mathrm{l}$ and $\mathrm{Cp}$-s against $A$. stephansi have been presented in Figure 2. At lower $\mathrm{LD}_{50}$ and $\mathrm{LD}_{90}$ value, the mortality rate was higher for $\mathrm{Cp}$-l extract in comparison to all other samples studied.
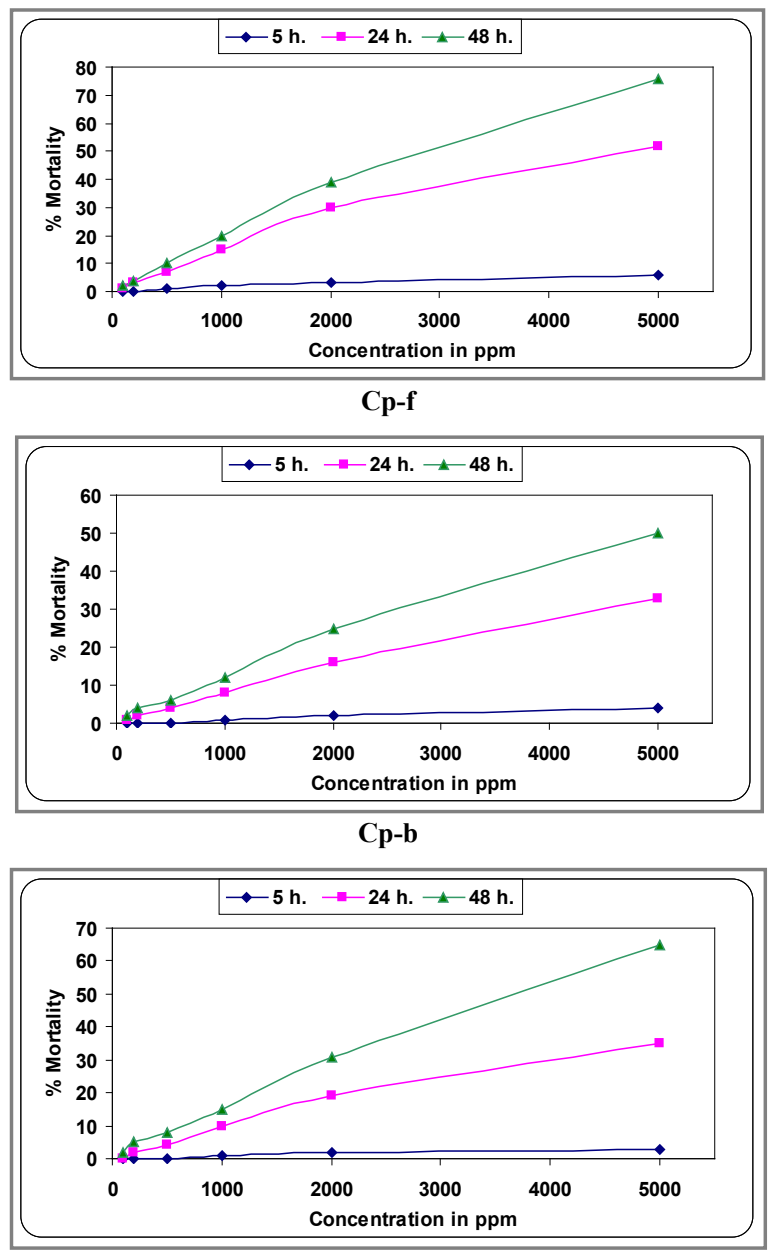

Cp-I

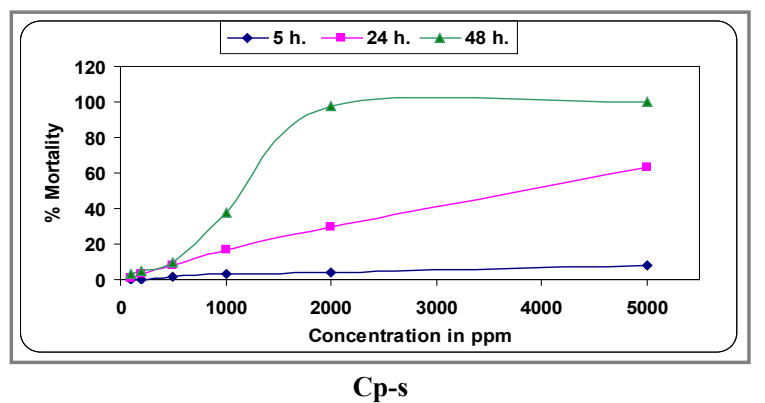

Figure 1. Effect of plant extract on $3^{\text {rd }}$ instar larvae of Anopheles stephansi at different concentration with respect to time.

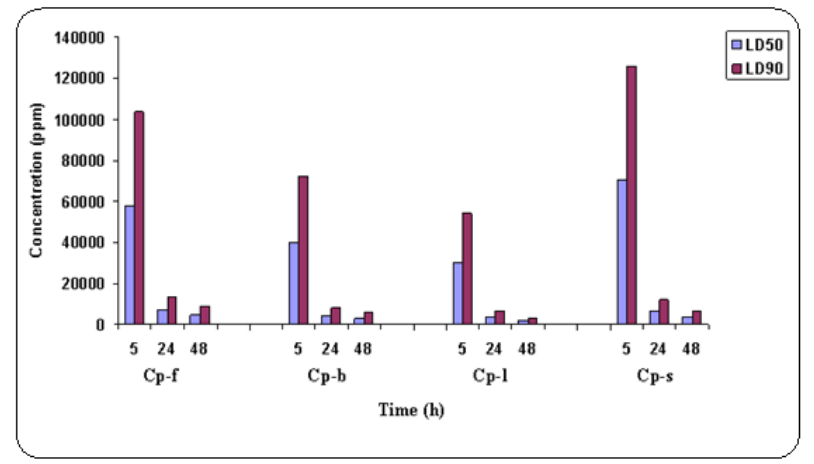

Figure 2. Comparison of $\mathrm{LD}_{50}$ and $\mathrm{LD}_{90}$ at different concentration with respect to time.

The mature leaves of $C$. procera had shown higher 
larvicidal activity against $A$. stephansi in laboratory conditions. Acute toxicity tests suggest that $C$. procera plant may be used safely in high doses[35]. The larvicidal action of the mature leaf extract of $C$. procera could be exploited against mosquito larvae.

\section{Conclusions}

The plant C. Procera is typically rich in most of the phytochemicals studied. $C$. procera possesses the antibacterial phytochemicals or toxins as evident by the formation of inhibition zone on the plate surface containing bacterial strain. Therefore, either plants or plant parts could be processed and used against many micro-organisms. The mature leaves of $C$. procera could be the best option to extract the phytochemicals and their uses against the larvae of $A$. stephansi.

\section{ACKNOWLEDGMENTS}

We thank Charutar Vidya Mandal, New Vallabh Vidyanagar for providing facility and financial support to undertake the research work. Authors acknowledge Dr. H. C. Srivastava and Mr. Sukhmaya Banerjee, National Institute of Malaria Research (ICMR), Civil Hospital Nadiad, Gujarat, for their technical support.

\section{REFERENCES}

[1] Farnsworth, N.R. and D.D. Soejarto, 1985, Potential consequences of plant extinction in the United States on the current and future availability of prescription drugs, Econ. Bot., 39(3), 231-240.

[2] Farnsworth, N.R.,1998, Screening plants for new medicines, in Biodiversity (Wilson EO, ed.), National Academic press, pp. 83-97.

[3] Ekhaise, F.O. and P. Okoruwa, 2001, Antibacterial Activity of Vera extract on Staphylococcus aureus, Trop. J. Environ. Sci. Health, 4, 28-31.

[4] Grasela, T.H., S.D. Goodwin and M.K. Walawander, 1990, Prospective surveillance of intravenous amphotericin B use patterns, Pharmacotherapy, 10, 341-348.

[5] Hillyer, J.F. and B.M. Christensen, 2001, Characterization of hemocytes from the yellow fever mosquito Aedes aegypti, Histochem. Cell Biol., 117, 431-440.

[6] Singh, R.K., R.C. Dhiman and P.K. Mittal, 2006, Mosquito larvicidal properties of Momordica charantia Linn. (Family: Cucurbitaceae), J. Vect. Borne Dis, 43, 88-91.

[7] Kumari, R., B.R Thapa, R.K. Dasgupta, S.M. Kaul and Shiv Lal, 1998, Susceptibility status of malaria vectors to insecticides in India, J. Com. Dis., 30(3), 179-85.

[8] Thomas, T.G., S.K. Sharma, S. Jalees and S.J. Rehman, 1994, Larvicidal properties of an indigenous plant Yucca aloifolia
Linn against mosquito larvae, J. Basic Appl. Bio. Med, 2: 53-5.

[9] Thomas, T.G., K. Raghavendra, Shiv Lal and V.K. Saxena, 2004, Larvicidal properties of latex from unripe fruits of Carica papaya Linn. (Caricaceae), J. Com. Dis., 36(4), 290-292.

[10] Pathak, N., P.K. Mittal, O.P. Singh, V. Sagar and P. Vasudevan, 2000, Larvicidal action of essential oil from plants against the vector mosquitoes, Anopheles stephansi (Liston), Culex quinquefasciatus (Say) and Aedes aegypti (L), Intl. Pest. Contr., 46, 53-5.

[11] Mehra, B.K. and P.K. Haridhar, 2001, The effect of crude acetone extract of Annona squamosa Linn (Family: Annonaceae) on possible control potential against larvae of Culex quinquefasciatus, Say. J. Entomol. Res., 24(4), 141-6.

[12] Singh, S.P., K. Raghavendra, R.K. Singh and S.K. Subbarao, 2001, Studies on the larvicidal properties of leaf extract of Solanum nigrum Linn. (Family: Solanaceae), Curr. Sci. 81(12), 1529-30.

[13] Singh, R.K., P.K. Mittal and R.C. Dhiman, 2005, Laboratory study on larvicidal properties of leaf extract of Calotropis procera (Family: Asclepiadaceae) against mosquito larvae, J. Com. Dis., 37, 109-113.

[14] Mittal, P.K. and S.K. Subbarao, 2003, Prospects of using herbal products in the control of mosquito vectors, ICMR Bull., 33(1), 1-10.

[15] Dharmagadda, V.S.S., S.N. Naik, P.K. Mittal and P. Vasudevan, 2005, Larvicidal activity of Tagetus patula, Bioresource. Technol., 96, 1235-1240.

[16] Da Cunha, M.P., J.B.P. Lima, W.G. Brogdon, G.E. Moya and D. Vale, 2005, Monitoring of resistance to the pyrethroid cypermethrin in Brazilian Aedes aegypti (Diptera: Culicidae) populations collected between 2001 and 2003, Mem. Inst. Oswaldo. Cruz., 100, 199-203.

[17] Carvalho, A.F.U., V.M.M. Melo, A.A. Craveiro, M.I.L. Machado, M.B. Bantim and E.F. Rabelo, 2003, Larvicidal activity of the essential oil from Lippia sidoides Cham. against Aedes aegypti Linn, Mem. Inst. Oswaldo. Cruz., 98, 569-571.

[18] Chopra, R.N., S.L. Nayar and I.C. Chopra, 1956, "Glossary of Indian Medicinal Plants", Council of Scientific and Industrial Research, New Delhi, India, pp-46.

[19] Watt, J.M. and M.G. Breyer-Brandwijk, 1962, "The Medicinal and Poisonous Plants of Southern and Eastern Africa", $2^{\text {nd }}$ Ed., part-I, E and S. livingston Ltd. Edinburgh and London, pp- 125.

[20] Kupchan, S.M., J.R. Knox, J.E. Kelsey and J.A.S. Renauld, 1964, Calotropin, a Cytotoxic Principle Isolated from Asclepias curassavica L, Science, pp.-146.

[21] Bhatnagar, S.S. 1950, "The wealth of India", CSIR, New Delhi, 2, 23.

[22] Raman, N. 2005, Phytochemical Techniques and plant tissue Culture, Workshop manual. Centre for Advanced studies in Botany, University of Madras, Chennai, India.

[23] Sadasivam, S. and A. Manickam, 1996, Biochemical methods, $2^{\text {nd }}$ ed. New Age International Publishers (P) Limited, New Delhi, India. 
[24] Lowery, O.H., N.J. Roserbrough, A.L. Larr and R.J. Randall, 1951, Protein measurement with the folin- phenol reagent, J. Bio. Chem, 193, 265.

[25] Schanderi, S.H. 2005, Phytochemical Techniques and plant tissue culture, Workshop manual, Centre for Advanced studies in Botany, University of Madras, Chennai, India.

[26] Khanna, T.V. and P. Sairam, 1971, Effect of tyrosine and phenylalanine on growth and production of alkaloids in Datura tatula tissue culture, Lloydia, 34, 170-171.

[27] Dadhani, P.K., M. Agarwal and I. Sharma, 1987, Technique in seed science and Technology, Indian Agricultural institute, New Delhi.

[28] Walter H.T., U. Geipel, B. Leonhard and D. Bauer, 1998, Antibiotic Susceptibility Testing (Agar Disk Diffusion and Agar Dilution) of Clinical Isolates of Enterococcus faecalis and E. faecium: Comparison of Mueller-Hinton, Iso-Sensitest, and Wilkins-Chalgren Agar Media, Inoculum preparation, Int. J. Expt. Clin. Chemoth., 44(4), 230-237.

[29] Acharya, A.S., N.K. Acharya and A.P. Dash, 1991, Software for estimating LD50 and LD90 by logit analysis, Comput. Methods Programs Biomed. 34(4), 255-256.
[30] Mahran, G.H., S.M. Abdel-wahab and A.M. Abdel-wahab, 1976, Attia phytochemical study of date palm pollen, Planta-Medica, 29(2), 171-175.

[31] Mascolo, N., R. Sharma, S.C. Jain and F. Capasso, 1988, Ethnopharmacology of Calotropis procera flowers, J. Ethnopharmacol, 22, 211-221.

[32] Mossa, J.S., M. Tariq, A. Mohsin, A.M. Ageel, M.A. AI-Yahya, M.S. Al-Said and S. Rafatullah, 1991, Pharmacological Studies on Aerial Parts of Calotropis procera, A. J. Chinese Med., 19(3-4), 223-231.

[33] Patel, G.B. 2007, Dissertation thesis "Screening of bark extracts of some plants for antibacterial activity" Dept. of Biosciences, S.P. University, pp -14.

[34] Nikaido, H. and M. Vaara, 1985, Molecular basis of bacterial outer membrance permeability. Microbiol. Reviews, 1, 1-32.

[35] Ramos, M.V., G.P. Bandeira, C.D.T. de Freitas, N.A.P. Nogueira, N.M.N. Nunes Alencar, P.A.S. de Sousa and A.F.U. Carvalho, 2006, Latex constituents from Calotropis procera (R. Br.) display toxicity upon egg hatching and larvae of Aedes aegypti (Linn.), Mem. Inst. Oswaldo. Cruz. Rio de Janeiro, 101(5), 503-510. 